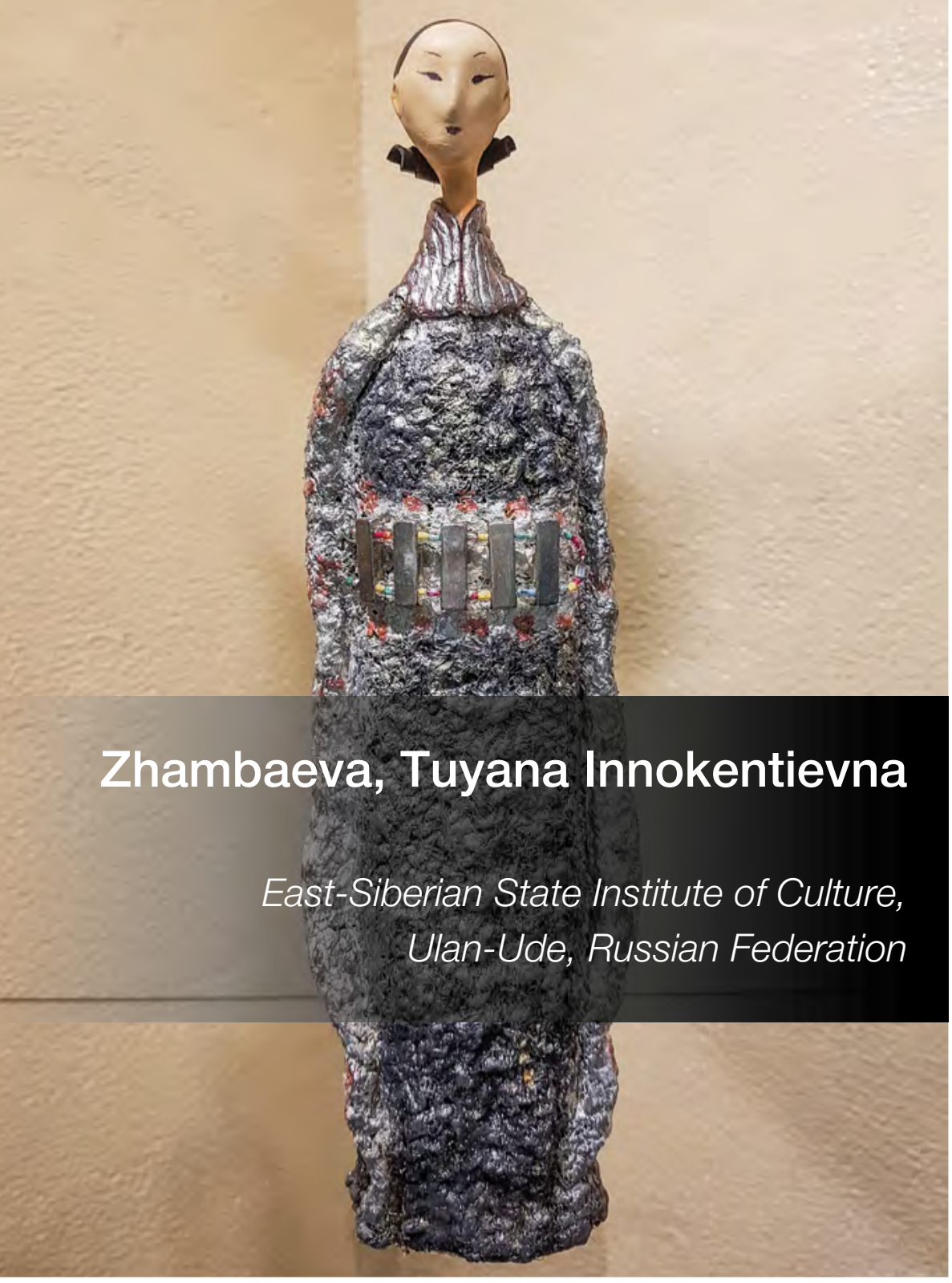

Жамбаева Туяна Иннокентьевна

Восточно-Сибирский государственный институт культуры, г. Улан-Удэ, Российская Федерация

«МИР ГОБЕЛЕНА БУРЯТИИ»: АНАЛИТИЧЕСКИЙ ОБЗОР

\title{
THE WORLD OF THE TAPESTRY
}

\section{ВЫСТАВКИ}

OF BURYATIA: ANALYTICAL REVIEW

OF THE EXHIBITION 


\section{АННОТАЦИЯ}

Автор представляет концепцию выставки, посвященной искусству гобелена этнической Бурятии - со времени его зарождения в регионе в 1970-х гг. до современности. Впервые в одной экспозиции были представлены работы пятнадцати авторов, выполненные в разных материалах и направлениях. Изложена цель выставочного проекта - показать творческие достижения художников, многообразие тем и сюжетов, отражающих специфику региона. В ходе подготовки к выставке использовались как теоретические, так и эмпирические методы исследования: изучались библиографические источники, проводились встречи, беседы с авторами для получения более полного и цельного представления о замысле произведений и характере создания. Объединение довольно разрозненных материалов в единую выставочную концепцию является сегодня актуальным для развития современного декоративно-прикладного искусства Бурятии в области мягких материалов. В статье представлено художественное пространство искусства гобелена, наполненное индивидуальным видением, объединенное спецификой выразительных средств в области ручного ткачества.

\section{КЛЮЧЕВЫЕ СЛОВА:}

Гобелен; Бурятия; национальное в искусстве; декоративно-прикладное искусство; конский волос; ручное ткачество; тема; шерсть.

\section{ABSTRACT}

The author presents the concept of an exhibition dedicated to the tapestry art of ethnic Buryatia since its inception in the region, in the 1970s to the present day. For the first time, in one exhibition were presented the works of 15 authors, performed in different materials and directions. The purpose of the exhibition project is to show the creative achievements of artists, the variety of themes and plots that reflect the specifics of the region. During the preparation for the exhibition, both theoretical and empirical research methods were used: bibliographic sources were studied, meetings, conversations with authors were held in order to obtain a more complete and holistic idea of the concept of the works and the nature of creation.

Combining rather disparate materials into a single exhibition concept is currently relevant for the development of modern decorative and applied art in Buryatia in the field of soft materials. As a result, the article presents a kind of artistic space of tapestry art, filled with an individual vision, united by the specifics of expressive means in the field of hand weaving.

\section{KEYWORDS:}

Tapestry; Buryatia; national in art; horsehair; decorative and applied arts; hand weaving; topic; wool. 


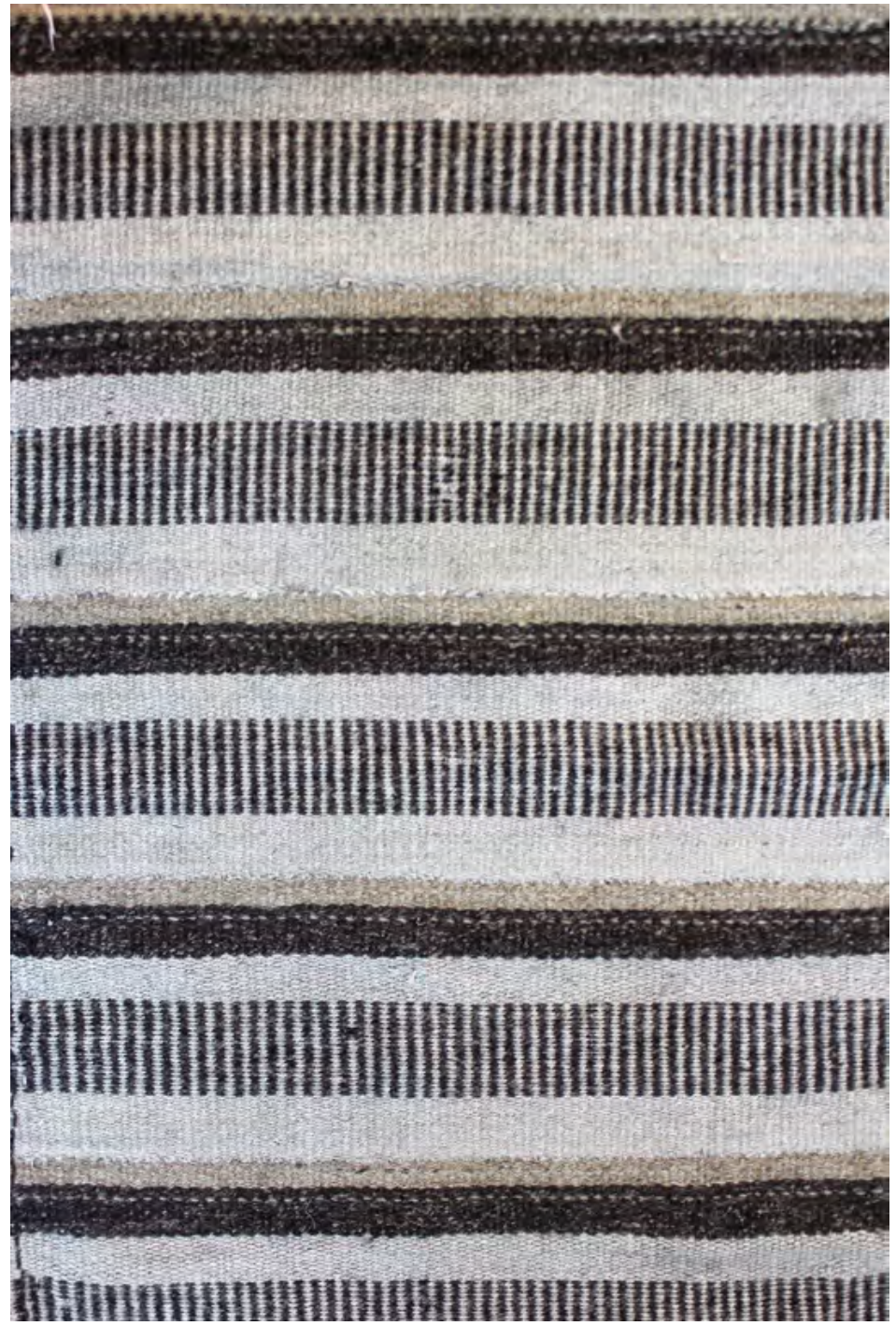

С конца XX века гобелен Бурятии получил активное развитие, отражающее события, творческие судьбы, рождение произведений искусства. Начиная с 1970-х гг. созданы произведения монументальные, станковые, мини-гобелены, близкие к бурятским коврам таарам (бур.). Многие произведения гобеленного ткачества Бурятии представляют собой удивительно прекрасные творения искусства и являются постоянными экспонатами межрегиональных, зональных, всероссийских и зарубежных выставок. Между тем художественное наследие в области гобелена в Республике Бурятия до сих пор не получило глубокого и подробного рассмотрения в искусствоведении.

Сегодня искусство гобелена в регионе испытывает определенные трудности, связанные с пополнением молодыми кадрами, есть потребность в увеличении мастерских, популяризации ручного ткачества, в том числе ткачества из пряжи конского волоса, среди населения. Сегодня актуален и вопрос преемственности, передачи опыта художественной обработки конского волоса от мастериц, чьи работы заслужили высокую оценку еще в 1980-1990-е годы. Решению этих вопросов способствуют художественные выставки бурятского гобелена.

С этой целью в Национальном музее Республики Бурятия 19 февраля 2021 года открылась выставка «Мир гобелена Бурятии». Организовать ее удалось при стипендиальной поддержке Общероссийской общественной организации «Ассоциация искусствоведов». Проект призван представить развитие гобелена как цельное явление в области декоративно-прикладного искусства, отражающее национальный колорит этнического региона Бурятии.

В аннотации к выставке отмечено: «Произведения гобеленного искусства, представленные на выставке, несут индивидуальный авторский почерк и в то же время объединены идеей национального колорита в искусстве. В экспозицию включены произведения из фондов Национального музея Республики Бурятия, мастерских Союза художников Бурятии, фондов Усть-Ордынского Национального центра художественных народных промыслов, а также авторских коллекций: Тамары Тиминой, Солбона Ринчинова, Светланы Ринчиновой, Аллы Цыбиковой, Баярмы Дамбиевой, Татьяны Дашиевой, Риммы Доржиевой, Анжелики Алсаткиной, Ираиды Асхаевой, Алимы Цырендоржиевой, Татьяны Бадуевой, Екатерины Осиповой, Софьи Ли, Мэдэгмы Дандарон. Одна из первостепенных задач современности - передача опыта молодым художникам. С этой целью на выставке представлены дипломные работы студентов образовательных учреждений: Колледжа традиционных искусств народов Забайкалья (с. Иволгинск), художественного отделения Колледжа искусств им. П.И. Чайковского, кафедры декоративно-прикладного искусства Восточно-Сибирского государственного института культуры (г. Улан-Удэ)» [2].

Французское искусство гобелена получило на бурятской земле свой жизненный путь, обрело самобытные традиции, пережив свой расцвет здесь в 1960-1980-е годы. Практически сразу в Бурятии этот вид искусства обрел региональные черты, связанные с ткачеством из пряжи конских волос и обращением мастеров к сюжетным и декоративным композициям на национальную тематику.

Ручная техника ткачества роднит гобелены с народными традициями бурят - обработкой и плетением из конского волоса бытовых предметов, а также небольших ковров тааров. Многим народам известна техника полотняного ткачества, самого простого и древнейшего, когда между рядами вертикальных нитей основы скользит, словно ныряя, нить-уток. Таким способом ткались ковры таары из конского волоса с добавлением козьей шерсти [5, с. 9]. Тканые полосы выходили шириной от 20 см в зависимости от ширины берда, их подгоняли под нужный размер, сшивая между собой
1. Таар из козьей шерсти.

Конец XIX начало XX века. Иркутская губерния, Предбайкалье. Конский волос, козья шерсть, кустарное производство, ткачество станочное 


\author{
2. Е.Д. Тыпхеева. \\ Чесан. \\ 1983. \\ Конский волос, ручное \\ ткачество
}

(рис. 1). Само полотно отличалось плотностью, крепостью рядов. По точным словам Ю.Г. Худугуевой, «внешне неброские, они впечатляют своей изысканностью, декоративностью. В них кроется энергия, передаваемая особой пластикой формы и цвета, своеобразной орнаментикой строгих геометрических узоров, ... согласованных в строго продуманной четкой композиции, хорошо сочетающейся с простой и скромной обстановкой бурятского жилища...» [7, с. 171].

Опыт обработки конского волоса переняли: Т.Н. Тимина, С.П. Ринчинова, Н.И. Дульбинова, Е.Д Тыпхеева, Н.Д. Эрдынеева. Таар «Чесан» Е.Д. Тыпхеевой (1935-? г.р.) повторяет принцип бурятских тканых ковров в чередовании вертикальных полос белого, черного и коричневого цветов, в орнаментальных ритмических вариациях (рис. 2). Очень удачно и гармонично в коллективном поиске был найден синтез классического гобеленного ткачества и традиции обработки конского волоса, который получил свое второе рождение.

В Бурятской АССР одними из первых профессиональных художников в области текстиля стали С.Р. Ринчинов и С.П. Ринчинова. Солбон Раднаевич Ринчинов (1936-2014) известен в большей степени как график и живописец. В то же время он в 1966 г. окончил Ленинградское высшее художественно-промышленное училище им. В.И. Мухиной, факультет «Интерьер и оборудование» на отделении текстиля у доцента С.М. Бунцис. В первые годы после приезда на родину в творческом союзе Солбона и Светланы Ринчиновых рождаются гобелены в технике ручного ткачества из шерстяной пряжи: «Песнь о Бурятии», «Состязание баторов», «Мать Бурятия», «Степь цветет», «Мелодия» и другие. Гобелены по эскизам С.Р. Ринчинова хранятся сегодня в фондах Национального музея Республики Бурятия и свидетельствуют о привнесении нового вида искусства в художественную жизнь Бурятии в конце 1960-х - 1970-е годы.

Солнечным теплом наполнен гобелен «Мелодия» (1977), выполненный в технике классического гладкого двухстороннего ткачества. Тонкое вкрапление нитей розовато-сиреневых, охристых, сине-зеленых цветов создает впечатление импрессионистического стилевого приема, вибрация нитей зернистой фактуры напоминает старинные шпалеры, но яркими охристыми пятнами внимание привлекают азиатские, смуглые лица, и зритель ощущает дыхание Востока (рис. 3). Композиция работы построена по вертикали - плавной линией соединены фигуры двух музыкантов и силуэты юрты, сэргэ (бур. коновязь). Один из музыкантов представлен в характерной позе лимбиста, с тонким рисунком пальцев, извлекающих звуки мелодии. Второй музыкант вторит ему, водя смычком по струнам морин-хура (бур.). Его прикрытые глаза

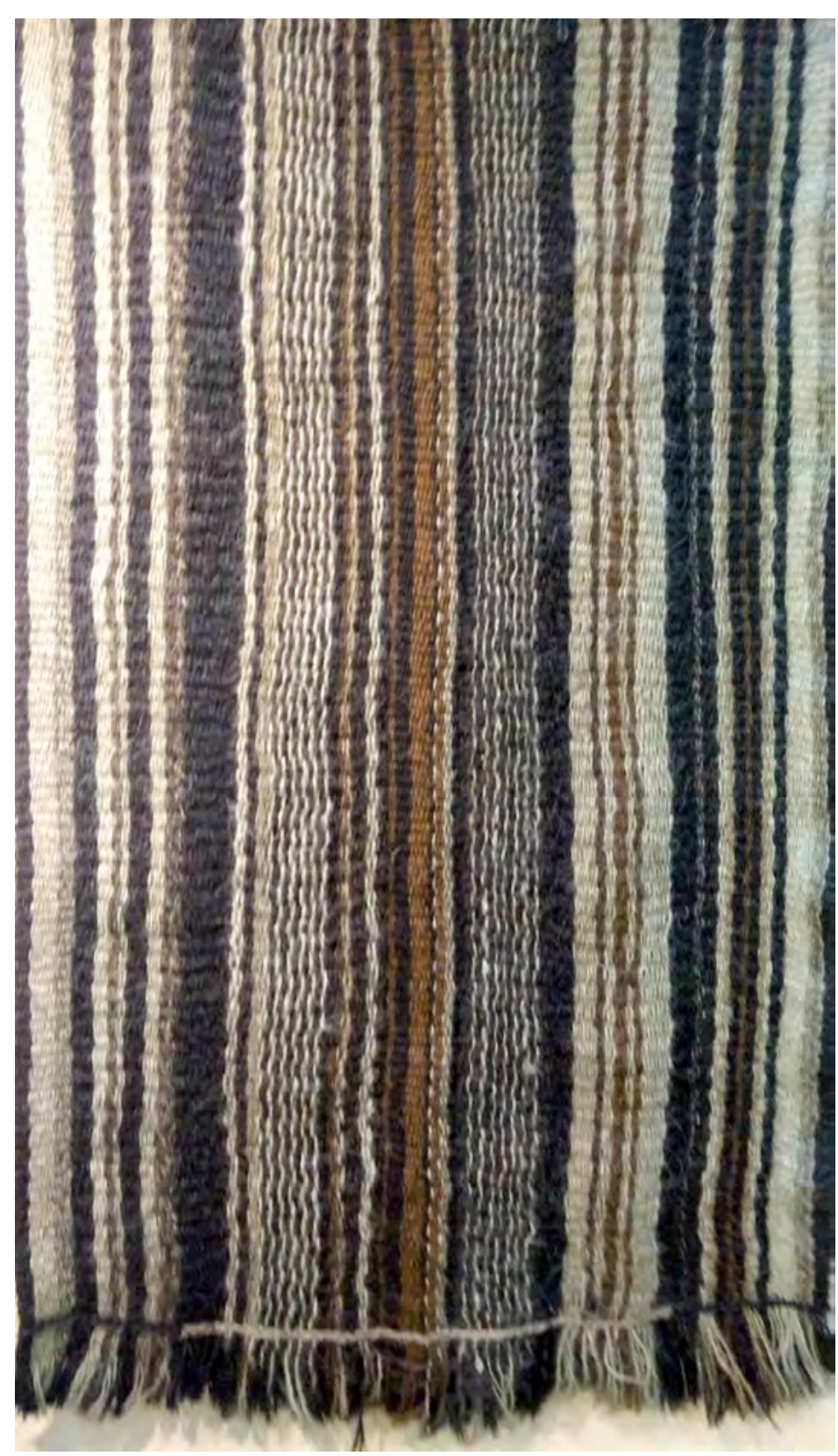

и склоненная линия головы подчеркивают единство дуэта.

Светлана Петровна Ринчинова (1939 г.р.), будучи студенткой Ленинградской консерватории им. Н.А. Римского-Корсакова, вольнослушателем посещала занятия доцента С.М. Бунцис в Ленинградском высшем художественно-промышленном училище им. В.И. Мухиной. С.П. Ринчинова - автор известных работ «Литэ» (бур. календарь), «Байкал», «Вечное движение», «Табунщики», «Весть Победы», «Мирный космос» и других. «Поистине, триумфальное шествие их по престижным российским, всесоюзным и зарубежным выставкам падает на 80-90-е годы»,- - пишет историк бурятского искусства А.В. Тумахани [4, с. 10]. Огромная работа была проделана по созданию гобелена-занавеса «Ургы» (бур. подснежник) в Бурятском академическом театре драмы им. Х. Намсараева по эскизу С.Р. Ринчинова, Э.Б. Аюшеева, Д.-Н.Д. Дугарова. 


\section{Искусство Евразии}

\section{№1 (20) 2021 elSSN 2518-7767}
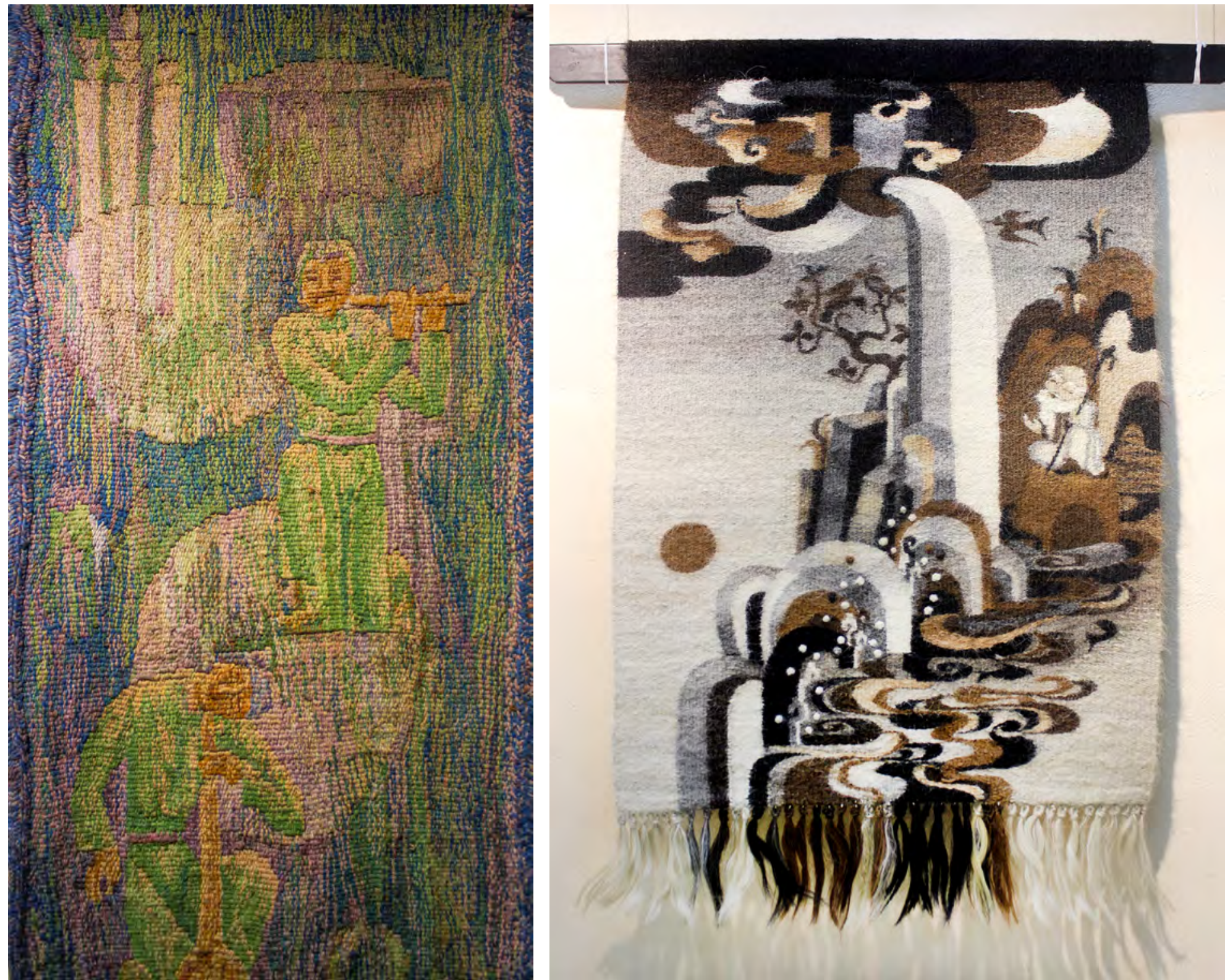

3. С.Р. Ринчинов

(автор), С.П. Ринчинова (исполнитель). Мелодия.

1977.

Шерсть, ручное ткачество

4. А.О. Цыбикова (автор).

Б.Д. Дамбиева (ткач).

Белый старец.

1991.

Конский волос, ручное

ткачество

С.П. Ринчинова была назначена руководителем коллектива гобеленщиц, им предстояло соткать занавес 12 × 8,40 м, весом около тонны. Этот занавес остается неповторимым уникальным произведением ручного ткачества из конского волоса.

Одна из известных работ — «Солнце» выполнена в технике ткачества из конского волоса. Солнечный диск с мощными лучами словно вправлен в квадрат рамы. Прием открытых нитей основы создает определенную легкость, воздушность. На этом фоне отчетливо читается орнаментальный мотив алтан хээ (бур.) и рисунок лучей, в некоторой неровности линий чувствуется эпическая сила и первозданность Востока.

Значительный вклад в развитие искусства гобелена в Бурятии внесла художник Алла Цыбикова (1951-1998). Ее работы в станковой живописи, монументальной росписи, гобелене связаны с поиском национального в современном бурятском искусстве. Заинтересовавшись гобеленным ткачеством из конского волоса, «Алла Цыбикова создала ряд эскизов монументальных гобеленов для общественных зданий Республики Бурятия: "Водопад" (1983, 250 × 600) в исполнении Б. Дамбиевой и Т. Дашиевой; "Богатый край” (1985, 229 x 600) в исполнении Б. Дамбиевой, Т. Дашиевой, Р. Доржиевой; “Облачный край” (1988, 220 × 600) в исполнении Б. Дамбиевой, Т. Дашиевой, Р. Доржиевой» [1, с. 270]. На выставке представлены работы Аллы Цыбиковой «Лотос», «Пейзаж», «Пейзаж. Вода», «Белый старец» (рис. 4).

В многолетнем творческом союзе Баярмы Дамбиевой (1948 г.р.) и Аллы Цыбиковой созданы такие гобелены, как «Сотворение», «Лотос», «Белый старец», «Родник» и другие. Мастерское исполнение точно передает замысел художницы Аллы Цыбиковой, все детали вытканы бережно, с любовью. Ткачество Баярмы Дамбиевой всегда можно отличить по изяществу полотна, плавной игре оттенков, теплой цветовой гамме. 


\section{5. Б.Д. Дамбиева.} Код жизни.

2016-2018.

Конский волос, ручное ткачество

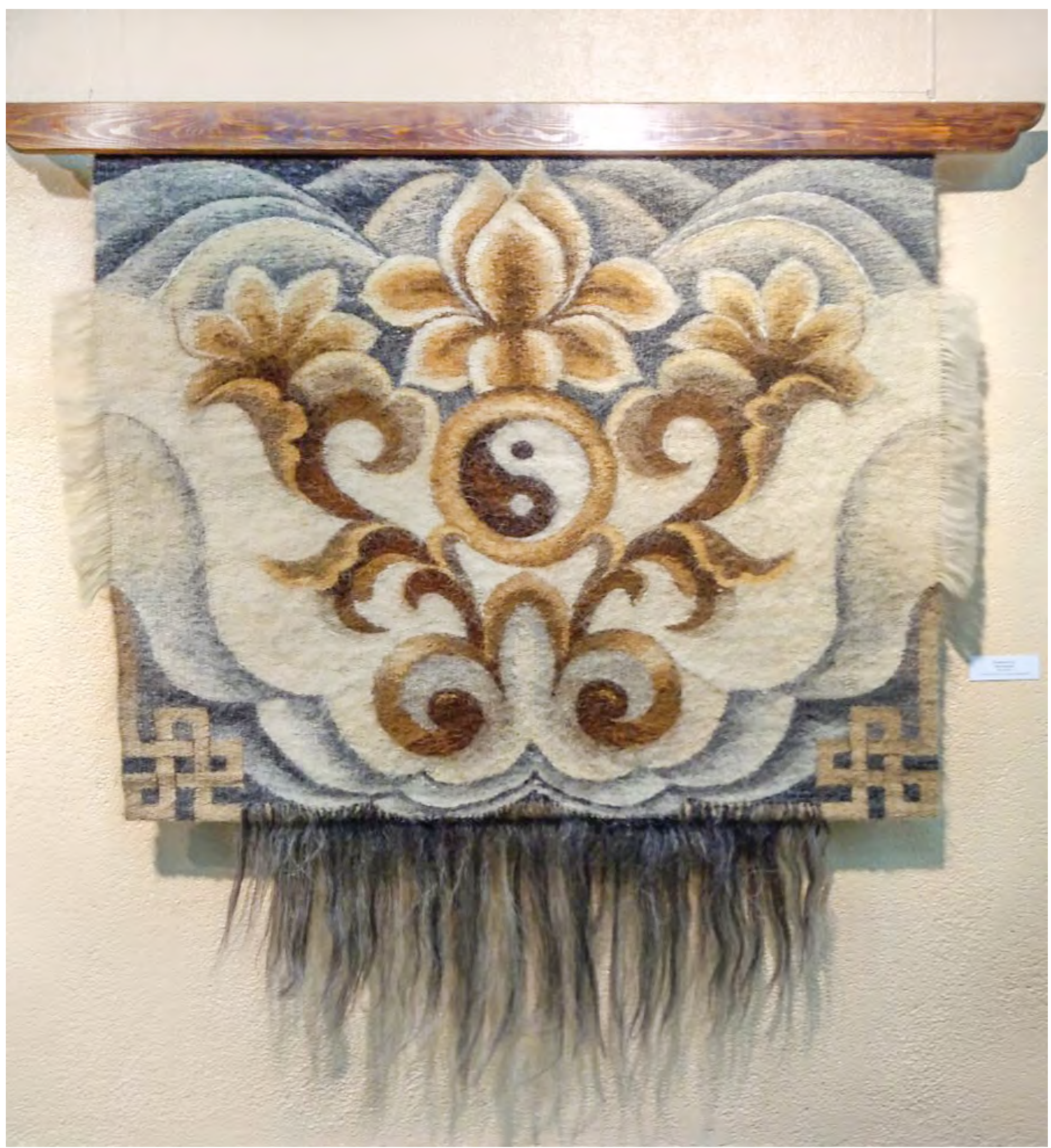

Авторские гобелены Баярмы Дамбиевой проникнуты знанием истории края, родного языка, орнамента и символики бурятской традиционной культуры. Гобелен «Код жизни» (2018) воплощает концепцию жизненного цикла номадов, «некий "код жизни степняка", как говорит сама гобеленщица (рис. 5). Композиция имеет форму чаши или "чаши жизни", в ее основании расположен мотив хамор угалз (бур. воловьи ноздри), несущий символику приумножения здорового скота, от него идут стебли и цветы, несущие благопожелание процветания степи. <...> В центре работы изображен инь-ян (кит.), фундаментальный знак всех жизненных процессов, развивающихся по закону единства противоположностей. Завершает композицию цветок лотоса, его сияние разливается по степи, словно благословение к процветанию. В нижних углах размещен орнаментальный мотив улзы (бур.), 


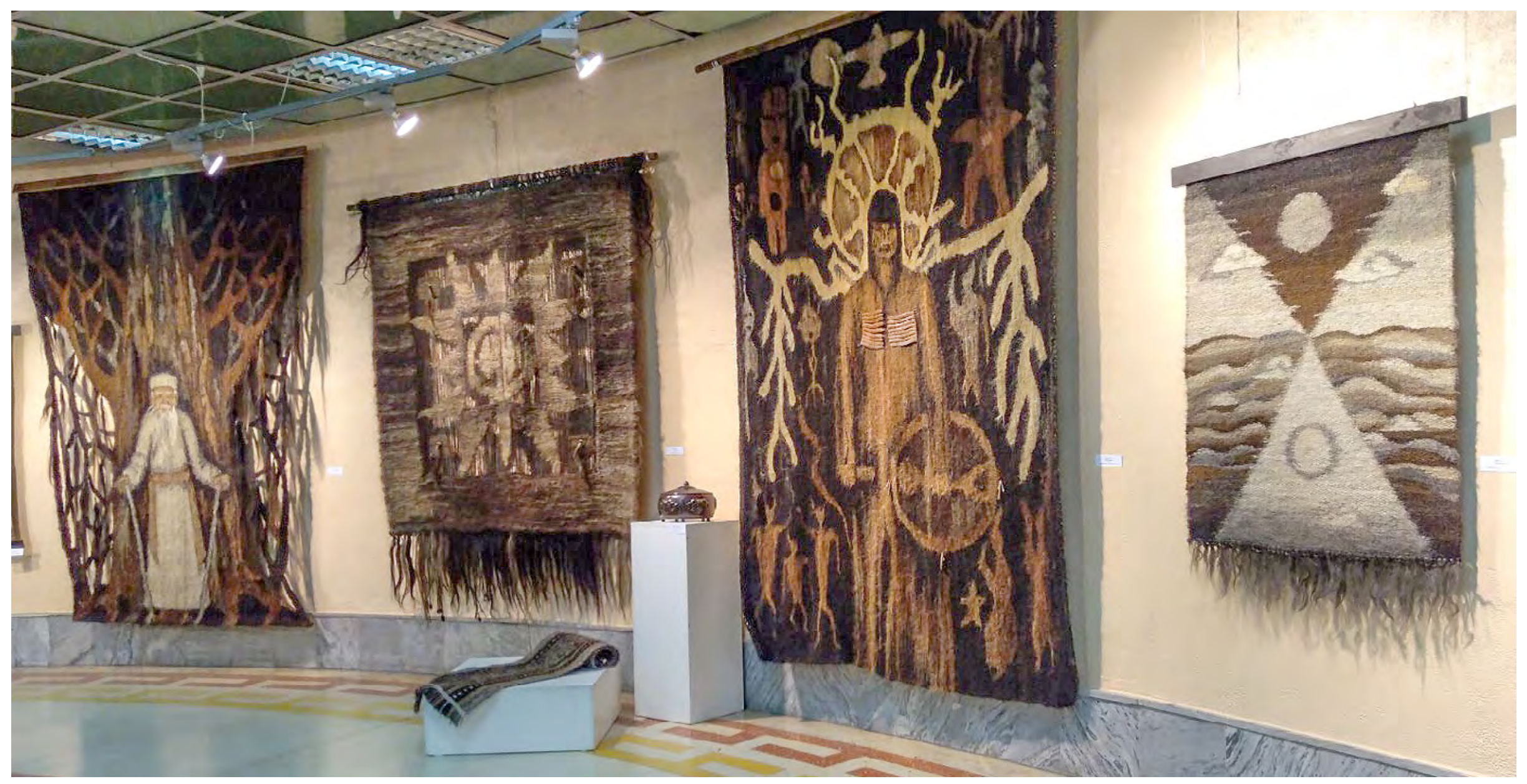

означающий благополучие, счастье, долголетие» [3, с. 55]. В этом гобелене Баярма Дамбиева нашла удивительно мягкую светлую гамму теплых оттенков бежевого, золотисто-желтого. «Используя традиционный подход, я стремлюсь показать возможности конского волоса; считаю, что они еще не до конца раскрыты, а для этого необходим творческий поиск и работа» [3, с. 55] (из беседы с Б.Д. Дамбиевой от 26.10.2019 г.).

В гобелене «Шаман-метаморфоз» Е.В. Осиповой (1983 г.р.) мы видим бесконечность времени и пространства, цепь перерождений и миров. Масштабное сотканное полотно так выразительно, правдоподобно, как будто само является частью обрядового действа. Центральная фигура шамана изображена с главным атрибутом - бубном, на его фоне чередой проходят духи трех миров (рис. 6).

В экспозицию вошли работы, призванные показать художественные возможности конского войлока, например в декоративных панно Т.Н. Тиминой, А.Б. Алсаткиной. Творчество А.Б. Алсаткиной — яркий образец синтеза традиций и инноваций. Автор чутко видит художественные возможности материала - войлока, конского волоса, камня, раскрывая их фактуру, связанную с тематикой произведений (рис. 7).
Профессиональный керамист Тамара Тимина не менее ярко и успешно проявила себя в области мягких материалов: в войлоке, конском волосе, цветной шерсти, в таких техниках, как плетение, прикреп, ручное ткачество. «На одной из выставок в Прибалтике Тамару Тимину поразило плетение и ручное ткачество из пеньки, шерсти, морской травы сезаль. Вернувшись на родину, она стала искать материал... вспомнились изделия старых мастеров - из конского волоса и шерсти» [6, с. 4]. Творческий поиск и увлеченность Тамары Николаевны воплотились в таких работах, как «Уянга», «Байкал», «Цам», «Ольхон», «Святой Нос» и др., представленных на региональных, зональных и всесоюзных выставках.

На данной выставке показана работа «Сувенир» (1980) - это декоративное панно увлекает взгляд ритмичным рисунком, вариациями орнаментального мотива улзы (бур.) - символа счастья, благопожелания и долголетия (рис. 8). Применение белого и черного конского волоса в переплетении крупных узлов счастья, свисающие бахромой кисти придают произведению торжественный характер и ощущение старины.

Природа творчества Мэдэгмы Дандарон естественна и гармонична, проявляется как отражение внутреннего духовного мира и видения красоты

\section{6. Е.В. Осипова.}

Шаман-метаморфоз. 2010.

Конский волос, ручное ткачество.

В экспозиции

«Мир гобелена Бурятии», второй экспонат справа 

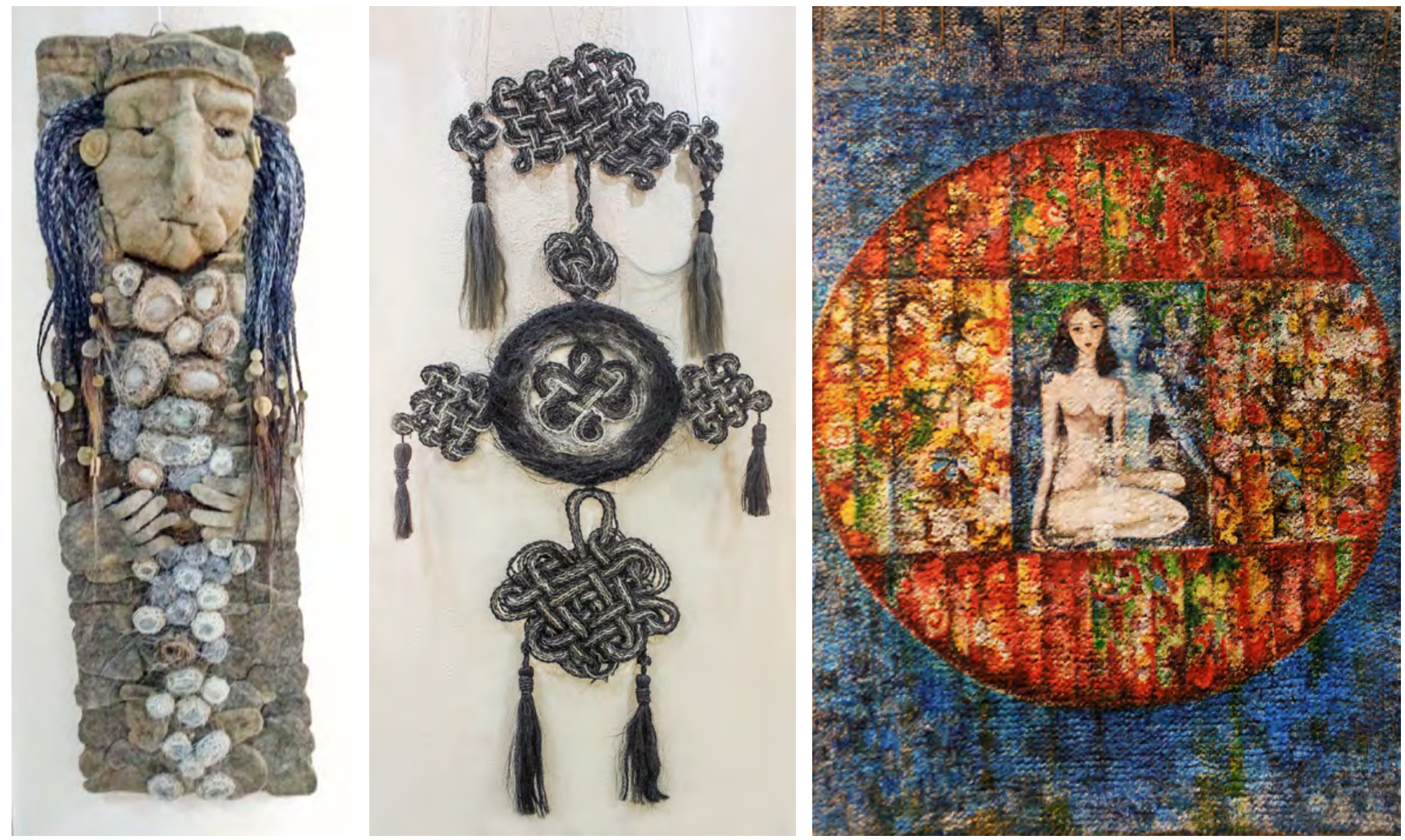
\begin{tabular}{c|c|cc}
7 & 8 & 9 & $\begin{array}{l}\text { мира окружающего. Одна из сторон ее многогран- } \\
\text { ного таланта - живопись, а с некоторого време- }\end{array}$
\end{tabular} ни и искусство нетканого гобелена. Еще в 2014 г. в Москве состоялась выставка живописных работ М. Дандарон «Путь Алая-Виджняны», посвященная 100-летию со дня рождения отца, Бидии Дандарон. В 2016 г. в галереe «Boccara» в Париже, на персональной выставке «Дух Сибири» мастер впервые представила работы в экспериментальной технике, соединив вязание, грунтование по авторской технологии и живопись акрилом. Прекрасно зная историю искусства, разбираясь в современных трендах, Мэдэгма Дандарон начала поиски смешанной техники в этом направлении. «С неровной и фактурной поверхностью работать достаточно непросто»,- - говорит автор (из беседы с М.Б. Дандарон 20.01.2021). На выставке «Мир гобелена Бурятии» представлены нетканые гобелены (рис. 9) и куклы в той же технике, эти работы были выполнены в 2020 г. (рис. 10,11).

В целом на выставке в Национальном музее Республики Бурятия можно заметить, что каждая гобеленщица выработала свой авторский почерк, обладая собственным видением и индивидуальной манерой ткачества. Мы можем увидеть монументальные и торжественные гобелены Светланы Ринчиновой; с искренней простотой переданы горы Закамны, фигуры людей, сарлыков, лошадей в работах Татьяны Дашиевой; удивительно тонко, словно кистью, выписаны детали в гобеленах Баярмы Дамбиевой, передающие богатство полутонов и упругих линий; поэзией и лирикой наполнены гобелены Риммы Доржиевой.

С середины 1990-х годов начинает работать поколение их учеников: Татьяна Бадуева и Софья Ли (мастерская Т.Ц. Дашиевой), Алима Цырендоржиева (мастерская А.О. Цыбиковой и Б.Д. Дамбиевой) и другие. Классический гобелен из цветной шерсти создает И.А. Асхаева (выпускница отделения ткачества ковров и гобеленов Московского художественно-промышленного училища), ее работы запоминаются изящным силуэтом фигур, певучими линиями волшебных цветов и птиц; в переливах сотканных нитей они несут впечатление сказки.

Надо отметить, что сегодня центрами сохранения традиций являются образовательные учреждения республики, где ведется преподавание по классу гобелена: Колледж традиционных искусств народов Забайкалья (с. Иволгинск), художественное отделение Колледжа искусств им. П.И. Чайковского (г. Улан-Удэ), кафедра декоративно-прикладного искусства Восточно-Сибирского государственного института культуры (г. Улан-Удэ). 
Искусство Евразии

№1 (20) 2021 elSSN 2518-7767
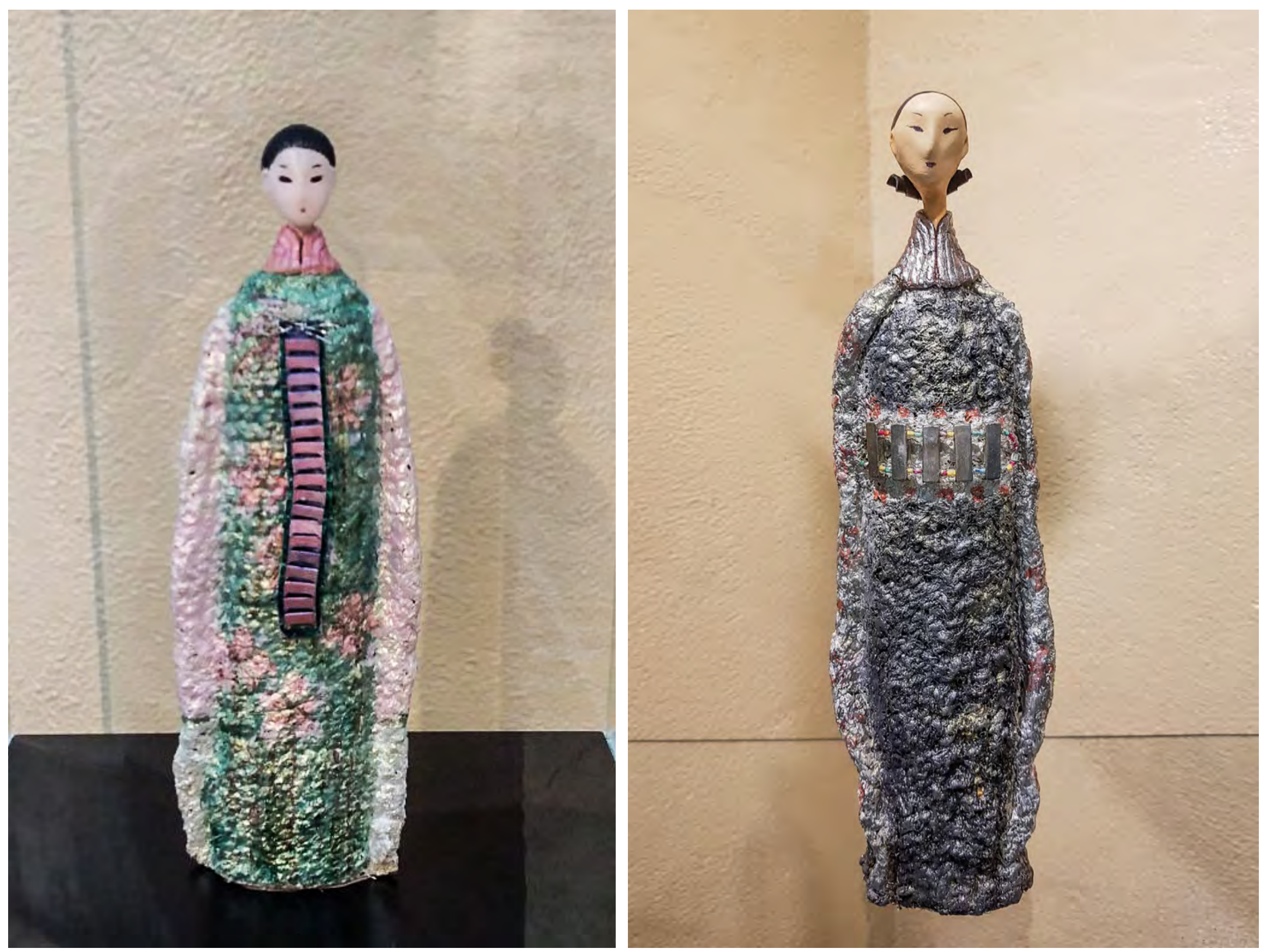

10. М.Б. Дандарон.

Кукла.

2018-2019.

Смешанная техника

11. М. Б. Дандарон.

Кукла.

2018-2019.

Смешанная техника 


\section{Литература}

1. Алла Цыбикова: альбом / сост. И. Дятловская. [Б. м.], 2006. 272 с.

2. Выставка «Мир гобелена Бурятии» откроется в Национальном музее Бурятии // Национальный музей Республики Бурятия [официальный сайт]. URL: http://2020.muzeyrb.ru/2021/02/16/vystavka-mir-gobelena-buryatii-otkr/ (дата обращения: 19.02.2021). 3. Жамбаева Т.И. Художественные особенности бурятского гобелена на примере творчества Баярмы Дамбиевой // Декоративное искусство и предметно-пространственная среда. Вестник МГХПА. 2019. № 4-2. С. 52-57.

4. Заслуженный художник Бурятской АССР Светлана Ринчинова: Гобелен, батик. Каталог выставки / Авт. вступ. ст. и сост.

Л.А. Константинова. М.: Советский художник, 1992. 12 с.

5. Мэрдыгеев Р.С. Изделия из шерсти и волоса в Аларском аймаке // Бурятиеведение. Верхнеудинск, 1928. №I-III (V-VII). C. $139-149$.

6. Худугуева Ю.Г. «...Огонь, мерцающий в сосуде» // Правда Бурятии. 1999. 28 апреля. С. 4.

7. Худугуева Ю.Г. Гобелены Бурятии // Байкал. 2009. №4. С. 171-178.

\section{References}

1. Dyatlovskaya I. (comp.). Alla Tsybikova. Album. S. n., 2006. 272 p. (In Russian).

2. Vystavka "Mir gobelena Buryatii" otkroetsya v Natsional'nom muzee Buryatii [The exhibition "The World of the Tapestry of Buryatia" will open at the National Museum of Buryatia. Natsional'nyi muzei Respubliki Buryatiya [National Museum of the Republic of Buryatia]. Available at: http://2020.muzeyrb.ru/2021/02/16/vystavka-mir-gobelena-buryatii-otkr/ (accessed: 19.02.2021). (In Russian).

3. Zhambaeva T.I. Khudozhestvennye osobennosti buryatskogo gobelena na primere tvorchestva Bayarmy Dambievoi [Artistic features of the Buryat tapestry on the example of Bayarma Dambieva's creativity]. Dekorativnoe iskusstvo i predmetno-prostranstvennaya sreda. Vestnik MGKHPA - Decorative art and subject-spatial environment. Bulletin of MGHPA, 2019, No. 4-2, pp. 52-57. (In Russian). 4. Konstantinov L.A. (comp.). Zasluzhennyi khudozhnik Buryatskoi ASSR Svetlana Rinchinova. Gobelen, batik [Honored Artist of the Buryat Autonomous Soviet Socialist Republic Svetlana Rinchinova. Tapestry, batik. Exhibition catalog]. Moscow, Sovetskiy khudozhnik, 1992. 12 p. (In Russian).

5. Merdygeev R.S. Izdeliya iz shersti i volosa v Alarskom aimake [Wool and hair products in the Alar aimag]. Buryatievedenie — Buryatian Studies, 1928, No. I-III (V-VII), pp. 139-149. (In Russian).

6. Khudugueva Y.G. "...Ogon', mertsayushchii v sosude” [“... The fire flickering in the vessel”]. Pravda Buryatii — Truth of Buryatia, 1999, 28 April, p. 4. (In Russian).

7. Khudugueva Y.G. Gobeleny Buryatii [Tapestries of Buryatia]. Baikal, 2009, No. 4, pp. 171-178. (In Russian).

ИНФОРМАЦИЯ ОБ АВТОРЕ: Жамбаева Туяна Иннокентьевна — кандидат искусствоведения, доцент, преподаватель, Восточно-Сибирский государственный институт культуры, г. Улан-Удэ, Российская Федерация. E-mail: tuyana75@mail.ru

ABOUT AUTHOR: Zhambaeva, Tuyana Innokentievna - Cand. Sc. (Art history), associate professor of the Department of cultural studies and art history, the East-Siberian State Institute of Culture, Ulan-Ude. Russian Federation.E-mail: tuyana75@mail.ru

\section{Для цитирования |For citation:}

Жамбаева Т.И. «Мир гобелена Бурятии»: аналитический обзор выставки // Искусство Евразии [Электронный журнал]. 2021. № 1 (20). C. 298-307. DOl:https://doi.org/10.46748/ARTEURAS.2021.01.022 URL: https://eurasia-art.ru/index.php/art/article/view/180

Zhambaeva T.I. The World of the Tapestry of Buryatia: analytical review of the exhibition. Iskusstvo Evrazii - The Art of Eurasia, 2021, No. 1 (20), pp. 298-307. DOI: https://doi.org/10.46748/ARTEURAS.2021.01.022

Available at: https://eurasia-art.ru/index.php/art/article/view/180

(In Russian). 